\title{
MAKING USE OF MATHEMATICS for GCSE
}


Other titles in this series

Making Use of Biology for GCSE, P. Alderson and M. Rowland Making Use of Physics for GCSE, R. Kibble 


\section{MAKING USE OF MATHEMATICS for GCSE}

G. D. Buckwell and A. D. Ball

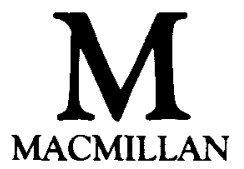


(C) G. D. Buckwell and A. D. Ball 1990

All rights reserved. No reproduction, copy or transmission of this publication may be made without written permission.

No paragraph of this publication may be reproduced, copied or transmitted save with written permission or in accordance with the provisions of the Copyright Act 1956 (as amended), or under the terms of any licence permitting limited copying issued by the Copyright Licensing Agency, 33-4 Alfred Place, London WC1E 7DP.

Any person who does any unauthorised act in relation to this publication may be liable to criminal prosecution and civil claims for damages.

First published 1990

Published by

MACMILLAN EDUCATION LTD

Houndmills, Basingstoke, Hampshire RG21 2XS

and London

Companies and representatives

throughout the world

Typeset by P \& R Typesetters Ltd, Salisbury, Wiltshire

British Library Cataloguing in Publication Data

Buckwell, G. D. (Geoffrey D.)

Making use of mathematics for GCSE

1. Mathematics

I. Title II. Ball, A. D. (Alan D.)

510

ISBN 978-1-349-10457-4 ISBN 978-1-349-10455-0 (eBook)

DOI 10.1007/978-1-349-10455-0

\section{Series Standing Order}

If you would like to receive future titles in this series as they are published, you can make use of our standing order facility. To place a standing order please contact your bookseller or, in case of difficulty, write to us at the address below with your name and address and the name of the series. Please state with which title you wish to begin your standing order. (If you live outside the United Kingdom we may not have the rights for your area, in which case we will forward your order to the publisher concerned.)

Customer Services Department, Macmillan Distribution Ltd Houndmills, Basingstoke, Hampshire, RG21 2XS, England. 


\section{CONTENTS}

Preface

vii

Acknowledgements

ix

1 Basic skills with numbers 1

2 Algebra 12023

3 Units of measurement and the metric system 43

4 Personal finance at work and in the home 69

5 Basic geometry and construction $\quad 103$

6 Mensuration 143

7 Trigonometry of right-angled triangles $\quad 169$

8 Using graphs 191

9 Probability 225

10 Statistics $1 \quad 245$

11 Algebra 2 277

12 Vectors, matrices and transformations $\quad 305$

13 Statistics $2 \quad 327$

14 Further topics, including surveying 361

$\begin{array}{ll}\text { Answers } & 391\end{array}$

$\begin{array}{ll}\text { Index } & 409\end{array}$ 


\section{PREFACE}

Many students find at the end of five years of secondary education that they still have not reached grade C standard in GCSE Mathematics. It is for these people that this book has been written. It is not aimed at any particular syllabus, but covers all of the topics needed at intermediate level for each examination group both at $16+$ and $17+$ levels, and also enough extra material to cover the $17+$ modular courses such as those offered by LEAG and SEG. Harder questions have also been included in the later chapters for students who are hoping to tackle the higher level of the GCSE examination.

The book does not have to be worked through from cover to cover, but it can certainly be used as a course text in this way if required. The approach adopted will help to rekindle the enthusiasm of the reader by putting the mathematics into context, and demonstrating its uses.

As coursework assignments are an essential part of the GCSE examination, a selection of ideas has been included at the end of each unit, though it is expected that many students may be continuing or improving investigational work which they have already presented in a previous examination.

The book contains many worked examples and exercises. A large number of actual examination questions are provided at the end of each unit, so that students may become experienced in approaching and tackling such questions.

The authors would like to record their thanks to Ann Ball and Josie Buckwell for their work in the preparation of the manuscript and also to Colin Prior for his super artwork.

Alan Ball

Geoff Buckwell 


\section{ACKNOWLEDGEMENTS}

The authors and publishers wish to thank the following who have kindly given permission for the use of copyright material: London East Anglian Group; Midland Examining Group; Northern Examining Association comprised of Associated Lancashire Schools Examining Board, Joint Matriculation Board, North Regional Examinations Board, North West Regional Examining Board and Yorkshire and Humberside Regional Examinations Board; Oxford and Cambridge Schools Examination Board; and Southern Examining Group for questions from specimen and past examination papers.

Every effort has been made to trace all the copyright holders, but if any have been inadvertently overlooked the publishers will be pleased to make the necessary arrangement at the first opportunity.

Please note that the answers given to the examination questions are the responsibility of the authors. They have not been provided or approved by the examination boards. 